American Journal of Applied Sciences 8 (10): 973-978, 2011

ISSN 1546-9239

(C) 2011 Science Publications

\title{
Impact of Grameen Bank Microcrdit Programme on Changing Livelihood Status of the Rural Women in Panchagarh District of Bangladesh
}

\author{
${ }^{1}$ Ferdoushi Ahmed, ${ }^{1}$ Chamhuri Siwar, \\ ${ }^{2}$ Nor Aini Hj. Idris and ${ }^{1}$ Rawshan Ara Begum \\ ${ }^{1}$ Institute for Environment and Development (LESTARI), \\ ${ }^{2}$ Economic Study Centre, Faculty of Economics and Management, \\ University Kebangsaan Malaysia, 43600, UKM, Bangi, Selangor D. E., Malaysia
}

\begin{abstract}
Problem statement: Rural women in Bangladesh are the most deprived part of the society and majority of them are extremely poor. They have very limited access to income generating activities and consequently less opportunity to improve their livelihood status. Microcredit programme contributes to improve the livelihood status of rural women in Bangladesh. Approach: This study examines the extent of changes in livelihood status of rural women through their involvement in the microcredit programme of Bangladesh. Results: The study reveals that the rural women, after joining the microcredit programme, have been able to engage themselves in income generating activities and consequently improved significantly their livelihood status. Conclusion: Therefore, it can be concluded that microcredit programme plays a significant role in changing and improving livelihood status among the rural poor families.
\end{abstract}

Key words: Rural women, microcredit programme, livelihood status, financial support, Micro Finance Institutions (MFIs), socioeconomic, income earning, Grameen Bank, social status

\section{INTRODUCTION}

Bangladesh is a least developing country of which more than $80 \%$ people live in rural areas (Sultana et al., 2010). Women constitute almost half of the total population in the world and out of which two third of world's adult illiterates are women (Sharma and Varma, 2008). Traditionally, Bangladesh is a patriarchal country where men dominate the family and enjoy full freedom in making decisions regarding their family matters (Islam et al., 2008). On the other hand, women, especially the rural women have lower status, in terms of socio-economic aspects, than men. They are the most deprived part of the society and majority of them are extremely poor. They have very limited access to income generating activities and consequently less opportunity to contribute to their family income (Ahmed et al., 2011a). In this circumstance, microcredit programmes are providing financial support to the deprived part of the society, especially rural women to improve their livelihood status through generating employment and income earning activities.
Grameen Bank, one of the largest Micro Finance Institutions (MFIs) in Bangladesh, provides small loans to the poor rural women to involve them in income producing activities so that they can improve their livelihood status. The prime objective of Grameen Bank's microcredit programme is to bring a fundamental change in social, economic and human development among the poor women in rural Bangladesh. Besides providing microcredit, Grameen Bank regularly organizes the weekly and monthly meetings in which the borrowers get together and discuss with each other about their family as well as social matters. It increases their social networks and extent of knowledge and consciousness about their rights, freedom and choices and duties and responsibilities to their family and society. In the recent decades, efforts have been concentrated on the development of innovative methods of credit schemes and programme to help the rural poor women (Momen and Begum, 2006). Moreover, women try to utilize the loans properly in order to improve their business and overall wellbeing of their families. Due to this reason, Grameen Bank emphasizes more to women than men in

Corresponding Author: Ferdoushi Ahmed, Institute for Environment and Development (LESTARI), University Kebangsaan Malaysia, 43600, UKM, Bangi, Selangor D. E., Malaysia Tel: +60143626210 Fax: +603-89255104 
providing the loans. By using the loans provided by Grameen Bank, the borrower women in rural areas are able to contribute more to increase their total family income (19\%) as compared to non-borrower women (10\%) (Ahmed et al., 2011b). The study conducted by Afrin et al. (2008) also found the better nutritional status of children as well as the ability to spend more on sanitation and health care of the borrower families as compared to the non-borrower families. Moreover, the members of Grameen Bank's microcredit programme have to attend the mandatory group meetings on weekly and monthly basis. In these meetings, the borrowers are given proper guidelines to utilize their funds according to their needs (Parveen, 2009). In addition, Grameen Bank provides other logistic supports such as training, skill development and various types of "consciousness rising" activities which gradually enhance their management ability, invigorate their self-confidence and consequently upgrade their decision making capabilities for profitable businesses. The most significant contribution of microcredit is increase in income and assets of the borrowers which automatically helps to better education, health, nutrition and self-esteem (Waheed, 2009).

This study aims to assess the extent of changes in socioeconomic status of rural women through their involvement in Grameen Bank's microcredit programme in Bangladesh. The study also attempts to evaluate the contribution of microcredit programme to improve the livelihood status of the rural poor women in terms of generating employment and income earning activities.

\section{METARIALS AND METHODS}

Survey design, sampling method, data collection and data analysis: Deriving accurate information is highly dependent upon the survey method. The direct face-toface interview is the most commonly used approach (Ogunlade and Adebayo, 2009) and is employed in this study. The data for this study is taken to reflect the objectives of the study. Data was collected through interview from the selected samples of Pachagarh Districts of rural women. In this study, sampling design was followed by "purposive random sampling" method. In the first stage of the survey and sampling, the study was purposively selected the samples of the rural women in the Panchagarh District. Grameen Bank members are chosen of respondents. For the samples, this study has selected 200 samples randomly from the listed (about 700) rural women of Grameen Bank members in the Pokhi Laga, Vetor gor, Chand para and Madhuban guchchho gram. The data were collected by the researcher herself using a pre-tested interview schedule and the period was from1st April 2008 to 30 June 2008.

After survey of the study, all the data were coded directly on questionnaires and then entered into personal computer. Several analyses of the data have been carried out in the core of this study. Simple descriptive statistics such as sums, means, percentages, frequency distributions are were used to analysis primary data for this study. This study utilised the Statistical Package for Social Science (SPSS) to analyse the data. This study also conducted social status index and economic status index to determine the change in livelihood status of the Grameen Bank members.

This study calculated Social Status Index (SSI) to ascertain the social status of 'with credit' rural women. Indeed, this index provides an indication of changes in social status of rural women. The formula for calculating SSI was taken from the study on poverty alleviation of rural women in Bangladesh, conducted by Islam et al. (2008). They measured SSI to observe the changes in social status rural women made after joining RDRS (Rangpur Dinajpur Rural Service), a local NGO in Bangladesh. This study computed SSI by applying the following formula.

Social Status Index $(\mathrm{SSI})=\sum \frac{\mathrm{wifi}}{\mathrm{n}} \times 100$

Where:

wi $=$ Weight

fi $=$ No. of Respondents

$\mathrm{n}=$ Total Respondents

Level of social status of 'with credit' rural women was the dependent variable of the social status function used in the study. It was measured on the extent of changes in social status of the respondents. A rating scale was used to measure the extent of changes in social status as perceived by 'with credit' respondents. The scale contained five selected indicators in which the respondents expressed their opinion. Each respondent indicated her perception regarding the change in her social status by putting tick mark on any one of the scores. The scale used for computing the extent of change in social status of the respondents is given below Table 1 .

Table 1: Scoring of social status

\begin{tabular}{ll}
\hline Types of social status & Scoring system \\
\hline 1.No change & 0 \\
2.Little change & 1 \\
3.Medium change & 2 \\
4.High change & 3 \\
5.Very high change & 4 \\
\hline
\end{tabular}


Am. J. Applied Sci., 8 (10): 973-978, 2011

Table 2: Scoring of economic status

\begin{tabular}{ll}
\hline Types of economic status & Scoring system \\
\hline 1.No change & 0 \\
2.Little change & 1 \\
3.Medium change & 2 \\
4.High change & 3 \\
5.Very high change & 4 \\
\hline
\end{tabular}

This study calculated Economic Status Index (ESI) to know the changes in economic status of 'with credit' rural women. This index indicates changes in households' economic condition. The formula for calculating SSI was taken from the study conducted by Islam et al. (2008). They measured ESI to determine the changes in economic conditions of rural women (members of RDRS) in some selected areas of Lalmonirhat District of Bangladesh. This study computed ESI by applying the following formula:

Economic Status Index $($ ESI $)=\sum \frac{\text { wifi }}{n} \times 100$

Where:

wi $=$ Weight

fi $=$ No. of Respondents

$\mathrm{n}=$ Total Respondents

Level of economic status of 'with credit' rural women was the dependent variable of the economic status function used in this study. The extent of changes in economic conditions of the respondents was measured by using a rating scale where the respondents indicated their perceptions by putting tick mark on any one of the scores. The scale contained five selected indicators in which the respondents expressed their opinion regarding the change in their economic status. The scale used for computing the extent of change in economic status of the respondents is given below Table 2.

\section{RESULTS AND DISCUSSION}

Contribution of microcredit to the improvement of social status: The findings of the study reveal that microcredit contributes significantly to develop social status or improve the quality of life of the poor rural women. The most important factors are types of housing, housing status and housing utility as these indicators contribute to the improvement of social status. Table 3 shows that GB members $(41.5 \%)$ own house compare to before they had (12\%). On the other hand, before they had landless $45 \%$ and now they are $20 \%$ landless. Before and after taking the loan about $33 \%$ respondents are living with family house.
Likewise, $10 \%$ had rental house and now $6 \%$ have rental house.

Table 3 also shows that before joining the GB's microcredit programme, $27.5,10$ and $12.5 \%$ of the respondents lived in bamboo house, earth house and building with tin shed house respectively. After being member of GB, the number of families living in earth house and building with tin shed house has increased sharply (27.5 and $31.5 \%$ respectively) though the number of residents of bamboo house have risen slightly $(35 \%)$. Here it is noticeable that there was no respondent family who lived in a fully building house (i.e., building with roof house) before being member of GB.

But after getting credit facilities from GB, 12 families (6\% of the 'with credit' respondents) have become able to afford a fully building house. A small proportion of the respondent families $(12.5 \%)$ used electricity before being member of GB and this figure increased dramatically to $65 \%$ after getting loans. This study found that none of respondent households use water supply before as well as after taking the loan from GB. The findings of this study indicate that rural women have become able to improve their social status after joining the Grameen Bank.

Impact of GB on social status: Findings related to social status are presented in Table 4. The Table shows that social status after involvement in the GB rose very highly in $20 \%$ of respondents 'households and $32 \%$ of respondents' households had high change of their social status. In about $35 \%$ of the households the change was medium and $12 \%$ had minor change. The value of weighted average index suggested that the respondents' households gained improvement in this social status by $65.37 \%$. Hence, it could be said that GB made a considerable improvement on the social status of the poor women members in the study areas.

Contribution to the improvement of economic activities: The findings of the Table 5 reveals that $84 \%$ of the respondents were not involved with any income earning activities before joining the GB. They were engaged with household chores. But only $2.0 \%$ of the respondents, after joining the $\mathrm{GB}$, did not directly participate in income earning activities. The findings indicate that the rate of women's participation in income earning activities has increased significantly after being member of GB. Consequently, it increases capabilities of the women to contribute to improve the economic wellbeing of their families. 
Am. J. Applied Sci., 8 (10): 973-978, 2011

Table 3: Improvement of Social Status in Grameen Bank Members

\begin{tabular}{|c|c|c|c|c|}
\hline \multirow[b]{3}{*}{ Type of housing status } & \multicolumn{4}{|c|}{ Responses } \\
\hline & \multicolumn{2}{|l|}{ Before } & \multicolumn{2}{|l|}{ After } \\
\hline & Number & Percent & Number & Percent \\
\hline \multicolumn{5}{|l|}{ Types of Housing: } \\
\hline Own house & 24 & 12.0 & 83 & 41.5 \\
\hline Family house (Parents house) & 66 & 33.0 & 65 & 32.5 \\
\hline Rental house & 20 & 10.0 & 12 & 6.0 \\
\hline Landless & 90 & 45.0 & 40 & 20.0 \\
\hline Total & 200 & 100.0 & 200 & 100.0 \\
\hline \multicolumn{5}{|l|}{ Building of House: } \\
\hline Bamboo & 55 & 27.5 & 70 & 35.0 \\
\hline Earth & 20 & 10.0 & 55 & 27.5 \\
\hline Building with tin shed (pacca bari) & 25 & 12.5 & 63 & 31.5 \\
\hline Building with roof (pacca bari chad dhalai ) & 0 & 0.0 & 12 & 6.0 \\
\hline Total & 200 & 100.0 & 200 & 100.0 \\
\hline \multicolumn{5}{|l|}{ Housing Utility: } \\
\hline No electricity & 175 & 87.5 & 70 & 35.0 \\
\hline Electricity & 25 & 12.5 & 130 & 65.0 \\
\hline Water supply & 0 & 0.0 & 0 & 0.0 \\
\hline Total & 200 & 100.0 & 200 & 100.0 \\
\hline
\end{tabular}

Source: Field Survey, 2008

Table 4: Social Status Index of with credit Respondent's Household

\begin{tabular}{lllll}
\hline $\begin{array}{l}\text { Types of } \\
\text { social status }\end{array}$ & Weight & $\begin{array}{l}\text { No. of } \\
\text { respondents }\end{array}$ & $\begin{array}{l}\text { Percentage } \\
\text { of respondents }\end{array}$ & $\begin{array}{l}\text { Index of } \\
\text { social } \\
\text { status }\end{array}$ \\
\hline No change & 0 & 2 & 1.0 & \\
Little change & 1 & 24 & 12.0 & \\
Medium change & 2 & 70 & 35.0 & $64.5 \%$ \\
High change & 3 & 64 & 32.0 & \\
Very high change & 4 & 40 & 20.0 & \\
Total & - & 200 & 100.0 & \\
\hline Source Field Survey, 2008 & & &
\end{tabular}

Source: Field Survey, 2008

Table 5: Economic Activities of GB Participant Before and After Programme

\begin{tabular}{|c|c|c|c|c|}
\hline \multirow[b]{3}{*}{ Economic activities } & \multicolumn{4}{|c|}{ Responses } \\
\hline & \multicolumn{2}{|l|}{ Before } & \multicolumn{2}{|l|}{ After } \\
\hline & Number & Percent & Number & Percen \\
\hline Housewife & 168 & 84.0 & 4 & 2.0 \\
\hline Private Servant & 0 & 0.0 & 4 & 2.0 \\
\hline Farmer & 28 & 14.0 & 134 & 67.0 \\
\hline Small Business & 4 & 2.0 & 54 & 27.0 \\
\hline Daily labour & 0 & 0.0 & 4 & 2.0 \\
\hline Total & 200 & 100.0 & 200 & 100.0 \\
\hline
\end{tabular}

Source: Field Survey, 2008

Table 6: Economic status index of 'with credit' respondent's household

\begin{tabular}{llccl}
\hline $\begin{array}{l}\text { Types of } \\
\text { economic } \\
\text { status }\end{array}$ & Weight & $\begin{array}{l}\text { No. of } \\
\text { respondents }\end{array}$ & $\begin{array}{l}\text { Percentage } \\
\text { respondents }\end{array}$ & $\begin{array}{l}\text { Index of } \\
\text { economic } \\
\text { of status }\end{array}$ \\
\hline No change & 0 & 4 & 2 & \\
Little change & 1 & 35 & 17.5 & \\
Medium change & 2 & 66 & 33.0 & $61.5 \%$ \\
High change & 3 & 55 & 27.5 & \\
Very high change & 4 & 40 & 20.0 & \\
Total & - & 200 & 100.0 & \\
\hline Sour
\end{tabular}

Source: Field Survey, 2008
The credit facilities provided by GB have significantly expanded income earning opportunities for the poor rural women. The borrower women, apart from their household chores, are engaged in various income producing activities, for example, small business, farming and other home-based economic activities (Table 5).

Here it can be noted that timely availability of credit and its proper utilization is a necessary condition for raising incomes of the 'with credit' respondents though there are other macro and micro exogenous factors that often affect the level of their incomes. However, the findings of this study demonstrate that GB's microcredit programme spreads out the income earning opportunities for the credit recipients, consequently increases household as well as per capita income and contributes significantly to alleviate poverty of the borrower households.

Impact of GB on economic status: Table 6 indicates that the economic status index of 'with credit' respondents. It is shown that the participation of women in GB would enable them to be employed in various income generating activities. As a consequence, the economic condition was sure to improve. The economic status index expressed the improvement in households' economic conditions. The Table shows that improvement in the index of economic status was estimated at $61.5 \%$. It is clearly evident that as a result of the participation of rural poor women in GB their economic condition has been improved substantially. 
Am. J. Applied Sci., 8 (10): 973-978, 2011

Table 7: Household sanitary facilities of the GB Member's

\begin{tabular}{|c|c|c|c|c|}
\hline \multirow{3}{*}{$\begin{array}{l}\text { Types of toilet } \\
\text { facility }\end{array}$} & \multicolumn{4}{|c|}{ Responses } \\
\hline & \multicolumn{2}{|l|}{ Before } & \multicolumn{2}{|l|}{ After } \\
\hline & Number & Percent & Number & Percent \\
\hline Open place & 25 & 62.5 & 12 & 6.0 \\
\hline Katcha ( Bamboo) & 55 & 27.5 & 50 & 25.0 \\
\hline Sanitary & 20 & 10.0 & 138 & 69.0 \\
\hline Total & 200 & 100.0 & 200 & 100.0 \\
\hline
\end{tabular}

Source: Field Survey, 2008

Table 8: Household sources of drinking water of the Grameen Bank Member's

\begin{tabular}{lcccc}
\hline & \multicolumn{3}{l}{ Responses } & \\
& --ofore & & After \\
Source of household & \multicolumn{2}{l}{ Before } & \\
drinking water & Number & Percent & Number & Percent \\
\hline Supply water & 0 & 0.0 & 0 & 0.0 \\
Tube-well & 110 & 55.0 & 180 & 90.0 \\
River/canal & 45 & 22.5 & 10 & 5.0 \\
Pond & 24 & 12.0 & 0 & 0.0 \\
Mat-well ( kua) & 21 & 10.5 & 10 & 5.0 \\
Total & 200 & 100.0 & 200 & 100.0 \\
\hline Source: Field Survey
\end{tabular}

Source: Field Survey, 2008

Improvement in health and sanitation: With respect to sanitary facilities (Table 7) the respondents indicated that a total of 200 households $69 \%$ had improved sanitary facilities and the corresponding number for the same respondents was much lower proportionally-a total of 200 households or $10 \%$ of the total. Before and after 27.5 and $25 \%$ of the respondents indicated they were still using the traditional katcha (bamboo) latrine. Before $62.5 \%$ respondents used open place for toilet while after $6 \%$ respondents using open place for toilet. In all categories, after participation of respondents fared "better" than the before participation of the respondents.

The primary sources of household drinking water are detailed Table 8, where the results from before and after participation in GB. After participation 90\% households using tube-well for drinking water while before participation they were used 55\% tube-well for drinking water. Before participation 22.5, 12 and 10.5\% households used river, pond for drinking water. After participation 5\% households still using river and matwell for drinking water. Table 8 also reveals all of the households after participation of the Grameen Bank microcredit programme they never using the pond for drinking water.

However, it is evident from Table 7 that use of sanitary toilets has increased tremendously in all the households. Use of katcha toilet has decreased and use of open place has reduced significantly in all the households. The participation of households using tubewell water has increased tremendously. At the same time rural women using river, pond and mat-well has decreased significantly (Table 8).

\section{CONCLUSION}

The study reveals that the rural women, after joining the Grameen Bank's microcredit programme, have been able to engage themselves in income generating activities and consequently improve significantly their livelihood status. It is reflected by the findings of the study. The results show that before joining the microcredit programme, only $12 \%$ of the respondents belonged to their own houses. But the proportion of the respondents having their own houses increased to $41.5 \%$ after joining the Grameen Bank. Similarly, 55\% of the respondent families used tubewell for drinking water before participating in microcredit programme. However, the proportion of the respondent families using tube-well increased to $90 \%$ after being members of the Grameen Bank. On the other hand, $45 \%$ of the respondents were landless before taking loans from Grameen Bank. But the proportion of landless families decreased to $20 \%$ after being members of microcredit programme. The study also found that the 'with credit' respondents gained improvement in the social status by $65.37 \%$ and economic status $61.5 \%$. The findings of the study indicate that the rural women, after joining the Grameen Bank's microcredit programme, were inspired and guided to undertake various income generating activities as well as contributed to increase the level of their family income. Therefore, the study suggests that microcredit programme of Grameen Bank acts positively to promote social and economic status of rural women and consequently improve their livelihood status. Finally, it can be concluded that microcredit programme plays a significant role in changing and improving livelihood status among the rural poor families.

\section{ACKNOWLEDGEMENT}

This study is supported and funded from the Commonwealth Scholarship and Fellowship Plan (CSFP) provided by Ministry of Higher Education, Malaysia. We are thankful to the International Programme Department of Grameen Bank for their kind permission to carry out the field works in the study areas. We are thankful to the Manager, Grameen Bank, Satmera Branch in Panchagarh District, Bangladesh for his much needed cooperation in collecting data from the respondents. We are really grateful to all the respondents for providing valuable information and 
data. An earlier version of this article was presented at the Annual Malaysia Input-Output Research Association (MIORA) Seminar on Development Challenges in a Climate of Change in Puri Pujangga Hotel, Bangi, Selangor, Malaysia, 1-2 April 2011.

\section{REFERENCES}

Afrin, S., N. Islam and S.U. Ahmed, 2008. A multivariate model of micro credit and rural women entrepreneurship development in Bangladesh. Int. J. Bus. Manage., 3: 169-185.

Ahmed, F., S. Chamhuri and A.H.I. Nor, 2011a. Contribution of rural women to family income through participation in microcredit: An empirical analysis. Am. J. Applied Sci., 8: 238-245. DOI: 10.3844/ajassp.2011,238.245

Ahmed, F., S. Chamhuri and A.H.I. Nor, $2011 \mathrm{~b}$. Contribution microcredit for improving family income of the rural women in panchagarh District of Bangladesh. Australian J. Basic Applied Sci., 5: 360-366.

Islam, M.M., R.N. Ali, M.M. Salehin and A.H.M.S. Islam. 2008. Rural women and poverty in alleviation in Bangladesh. J. Bangladesh Agric. Univ., 6: 415-421.
Momen, N and M. Begum, 2006. Impact of micro credit program for women development in Bangladesh: A case study of BRAC. Asian J. Inform. Technol., 5: 1269-1283. DOI: 10.3923/ajit.2006.1269.1283

Ogunlade, I. and S.A. Adebayo, 2009. Socio-economic status of women in rural poultry production in selected areas of Kwara State, Nigeria. Int. J. Poult. Sci., 8: 55-59.

Parveen, J.A., 2009. Sustainability issues of interestfree micro-finance institutions in rural development and poverty alleviation: The Bangladesh perspective. Theoretical Empirical Res. Urban Manage., 4: 112-133.

Sharma, P. and S.K. Varma, 2008. Women empowerment through entrepreneurial activities self help groups. Indian Res. J. Ext. Educ., 8: 4651.

Sultana, B., Z.B. Zaaba and K. Umemoto, 2010. Women's empowerment through the development of micro entrepreneurship in rural Bangladesh. J. Soc. Sci., 5: 1-9. DOI: 10.3923/sscience.2010.1.9

Waheed, S., 2009. Does rural micro credit improve well-being of borrowers in the Punjab (Pakistan)? Pak. Econ. Soc. Rev., 47: 31-47. 